\title{
Presence of HTLV in a Subset of T Cells from an Infected Patient: Some Immunochemical Properties of the Infected Cells
}

\author{
M. S. Reitz, D. Mann, M. F. Clarke, V. S. Kalyanaraman, M. Robert-Guroff, M. Popovic, \\ and R. C. Gallo
}

We have previously reported the isolation of a retrovirus (HTLV for human T-cell leukemia-lymphoma virus) from a patient with cutaneous T-cell lymphoma [3]. HTLV was shown to be unrelated to previously described retroviruses and not endogenous to humans, and integrated proviral DNA was present and expressed into mRNA in the malignant $T$ cells of the same patient [5]. A closely related virus was subsequently isolated from a patient with cutaneous T-cell leukemia-lymphoma [4]. Since then we (Popovic et al., in preparation; Gallo et al. and Sarin et al., this volume) and others [2] have also isolated virus from a number of other patients. All appear quite closely related to the first HTLV isolate (Popovic et al., submitted; Gallo et al., this volume).

Subsequent to the discovery of HTLV in two separate $T$-cell lines from the first patient (CR), we became aware of the existence of independently derived $T$ - and B-cell lines from the same patient, established in Dr. T. Waldmann's laboratory. This gave us the opportunity to determine the distribution of an HTLV-infected patient. The cell lines used in this study include: HUT-102, a TCGF-independent $T$-cell line established from the peripheral lymph node of CR using purified TCGF [4]; clones B2 and A9, TCGF-independent sublines of HUT-102 [1]; CTCL-3, TCGFdependent $\mathrm{T}$-cell lines established from the peripheral blood of $\mathrm{CR}$ using purified TCGF; CTC-16, TCGF-dependent T-cell line established from the peripheral blood of CR using crude TCGF [7]; C6 and G5, TCGF-dependent sublines derived from CTC-16 by the limiting dilution method; and $\mathrm{CR}-\mathrm{B}$, a B-cell line derived from peripheral blood after immortalization with Epstein-Barr virus strain B-95. The presence of HTLV was assayed in at least one of several ways: (1) p19 was assayed by indirect immunofluorescence using a murine monoclonal antibody; (2) p24 was assayed with a RIP assay using goat hyperimmune sera (see Sarngadharan et al., this volume); (3) RNA and (4) DNA were assayed by liquid hybridization as described by Reitz et al. [5].

HTLV was abundantly present in the HUT-102 line and the derived clones B2 and A9 (Table 1). The great majority $(\sim 90 \%)$ of these cells expressed p19, and provirus was present at three to four copies per haploid genome. CTCL-3 also contained HTLV, since $15 \%-20 \%$ of these cells

Table 1. Surface markers of HTLV-infected cells

\begin{tabular}{|c|c|c|c|c|c|c|}
\hline \multirow[t]{2}{*}{ Cell line } & \multirow[t]{2}{*}{ Virus } & \multicolumn{5}{|c|}{ OKT markers $(\%$ cell + ) } \\
\hline & & 3 & 4 & 6 & 8 & 10 \\
\hline
\end{tabular}

\begin{tabular}{llrrrrc}
\hline T cells & & & & & & \\
Clone B2 & ++ & 2 & 90 & 5 & 2 & 2 \\
Clone A9 & ++ & 5 & 70 & 5 & 5 & ND \\
CTCL-3 & + & 7 & 94 & 15 & 15 & 19 \\
CTC-16 & + & 29 & 86 & 12 & 6 & 5 \\
Clone C6 & $\pm^{\mathrm{a}}$ & 75 & 5 & 10 & 2 & 4 \\
Clone G5 & $\pm^{\mathrm{a}}$ & 26 & 5 & ND & 62 & ND
\end{tabular}

B cells

$\begin{array}{lllllll}\text { CR-B } & - & 5 & 5 & 75 & 5 & 5\end{array}$

ND, not done

a No p19 or proviral DNA detectable. Low levels of p24 present 
Table 2. HLA typing of cell lines derived from patient CR

\begin{tabular}{|c|c|c|c|}
\hline Cell lines & HLA-A & HLA-B & HLA-DR and MB \\
\hline \multicolumn{4}{|l|}{ T cells } \\
\hline HUT-102 & $\begin{array}{l}\text { Aw30, Aw31 } \\
\text { (A10), (A11), (A29) }\end{array}$ & $\begin{array}{l}\text { B17, B18 } \\
\text { (Bw35), (Bw50) }\end{array}$ & DR2, DRw6, MB \\
\hline B2 (HUT-102) & $\begin{array}{l}\text { Aw30, Aw31 } \\
\text { (A10), (A11), (A29) }\end{array}$ & $\begin{array}{l}\text { B17, B } 18 \\
\text { (Bw35), (Bw50), (B12) }\end{array}$ & DR2, DRw6, MB \\
\hline A9 (HUT-102) & $\begin{array}{l}\text { Aw30, Aw31 } \\
\text { (A10), (A11), (A29) }\end{array}$ & $\begin{array}{l}\text { B17, B18 } \\
(\text { Bw35), (Bw50), (B7) }\end{array}$ & DR2, DRw6, MB \\
\hline CTCL-3 & $\begin{array}{l}\text { Aw30, Aw31 } \\
\text { (A10), (A11) }\end{array}$ & $\begin{array}{l}\text { B17, B18 } \\
\text { (Bw35) }\end{array}$ & DR2, DRw6, MB \\
\hline G5 (CTC-16) & $\begin{array}{l}\text { Aw30, Aw31 } \\
\text { (A10), (A11), (A29) }\end{array}$ & B17, B 18 & DR2, DRw6, MB \\
\hline C6 (CTC-16) & Aw30, Aw31 & B17, B18 & DR2, DRw6, MB \\
\hline \multicolumn{4}{|l|}{ B cells } \\
\hline CR-B & Aw30, Aw31 & B17, B18 & DR2, DRw6, MB \\
\hline
\end{tabular}

express $\mathrm{p} 19$. In contrast, the B-cell line (like normal human $T$ cell) does not express either viral protein. Viral RNA and proviral DNA are not detectable even under conditions which would detect one proviral copy per eight haploid genomes.

CTC-16 also contains HTLV-infected cells since $35 \%-40 \%$ of the cells express p19. C6 and G5, derived from CTC-16, are negative for both p19 and proviral DNA (to a Cot of 20,000). Low levels of p24 are detectable $(\sim 1 \%$ of that observed with $B 2$ and A9). Our interpretation of this data is that $\mathrm{C} 6$ and $\mathrm{G} 5$ are not clonal with respect to HTLV provirus and that only a few cells are infected and producing protein. Since the p24 assay is more sensitive than the p19 assay under the conditions used, low levels of p19 expression could give a negative result.

All the cell lines were analyzed for surface markers with a FACS II cell sorter. The cells within the cultures with high levels of HTLV tended to be OKT $4^{+} 3^{-} 6^{-} 8^{-} 10^{-}$(Table 1 ). C6, which contained mostly uninfected cells, was predominantly OKT $3^{+} 4^{-} 6^{-} 8^{-} 10^{-}$, and G5 (also mostly containing uninfected cells) was largely OKT $8^{+3-4^{-}}$. Thus, in patient CT, HTLV appears to be mostly present in the peripheral blood in a particular set of $T$ cells.
All the cell lines used were typed for HLA expression in order to verify that they originated from CR. All had the same HLA-DR haplotype as the patient and all expressed HLA-Aw30 and Aw31 and HLA-B17 and -B18, consistent with the haplotype of fresh cells from CR and with that of his parents (Table 2). However, all the infected T-cell lines expressed extra, inappropriate HLA determinants on all of the cells, as judged by microcytotoxicity assays. This has now been observed with infected $T$ cells from six different patients and with cord blood $T$ cells infected with HTLV in vitro. DNA was purified from $T$ and $B$ cells, and digested with different restriction enzymes. We then hybridized these DNA digests to labeled HLA cloned DNA [6], by the Southern blot technique. Most restriction patterns for the two DNAs were similar, indicating that there are no massive rearrangements of the HLA gene complex. However, the patterns differed after digestion with $H p a I I$ and $X$ hol. Since these enzymes are inhibited by DNA methylation, this suggests that the band $T$ cells differ with respect to the degree of methylation of their HLA class I genes. Whether this is due to virus infection is a question of obvious interest. The exact nature of these possible methylation differences, as well as of the proteins which 
carry the apparently inappropriate HLA determinants, is currently under investigation.

\section{References}

1. Gallo RC, Mann D, Broder S, Ruscetti FW, Maeda M, Kalyanaraman VS, Robert-Guroff M, Reitz MS (to be published) Human T-cell leukemia-lymphoma virus (HTLV) is in Tbut not B-lymphocytes from a patient with cutaneous T-cell lymphoma. Proc Natl Acad Sci USA

2. Miyoshi I, Kubonishi I, Yoshimoto S, Akagi T, Ohtsuki Y, Shiraishi Y, Nagata K, Hinuma $Y$ (1981) Type $C$ virus particles in a cord T-cell line derived by cocultivating normal human leukocytes and human leukemic cells. Nature 294:770-771

3. Poiesz BJ, Ruscetti FW, Gazdar AF, Bunn PA, Minna JD, Gallo RC (1980) Detection and isolation of type-C retrovirus particles from fresh and cultured lymphocytes of a patient with cutaneous T-cell lymphoma. Proc Natl Acad Sci USA 77:7415-7419

4. Poiezs BJ, Ruscetti FW, Reitz MS, Kalyanaraman VS, Gallo RC (1981) Isolation of a new type-C retrovirus (HTLV) in primary uncultured cells of a patient with Sezary T-cell leukemia. Nature 294:268-271

5. Reitz MS, Poiesz BJ, Ruscetti FW, Gallo RC (1981) Characterization and distribution of nuclei acid sequences of a novel type- $\mathrm{C}$ retrovirus isolated from neoplastic human T-lymphocytes. Proc Natl Acad Sci USA 78: 1887-1891

6. Sood AK, Pereira D, Weissman SM (1981) Isolation and partial nucleotide sequence of a cDNA clone for human histocompatability antigen HLA-B by use of an oligodeoxynucleotide primer. Proc Natl Acad USA 78:616-620

7. Uchiyama T, Broder S, Bonnard G, Waldmann $T$ (1980) Immunoregulatory functions of cultured human T-lymphocytes. Trans Amer Assoc Physic 93:251-262 